\title{
Handbook of Florida Water Regulation: Florida Department of Environmental Protection ${ }^{1}$
}

\author{
Michael T. Olexa, Luke D'Isernia, Laura Minton, Dulcy Miller, and Sarah Corbett ${ }^{2}$
}

\section{Preface}

This handbook is designed to provide an accurate, current, and authoritative summary of the principle Federal and Florida laws that directly or indirectly relate to agriculture. This handbook should provide a basic overview of the many rights and responsibilities that farmers and farmland owners have under both Federal and Florida laws as well as the appropriate contact information to obtain more detailed information. However, the reader should be aware that because the laws, administrative rulings, and court decisions on which this handbook is based are subject to constant revision, portions of this publication could become outdated at anytime. Several details of cited laws are also left out due to space limitations.

This handbook is distributed with the understanding that the authors are not engaged in rendering legal or other professional advice, and the information contained herein should not be regarded as a substitute for professional advice. This handbook is not all inclusive in providing information to achieve compliance with the Federal and Florida laws and regulations governing water protection. For these reasons, the use of these materials by any person constitutes an agreement to hold harmless the authors, the Florida Cooperative Extension Service, the Institute of Food and Agricultural Sciences, and the University of Florida for any liability claims, damages, or expenses that may be incurred by any person as a result of reference to or reliance on the information contained in this handbook.

\section{Overview}

The Department of Environmental Protection (DEP) was created by the Florida Environmental Reorganization Act of 1993. Its primary responsibility is to preserve the environmental integrity of Florida's physical environment, especially air and water. Although this includes a large number of duties, only those duties relevant to the scope of this handbook are discussed. These include the following:

1. This is EDIS document FE593, a publication of the Food and Resource Economics Department, Florida Cooperative Extension Service, Institute of Food and Agricultural Sciences, University of Florida, Gainesville, FL. Published December 2005. Please visit the EDIS website at http://edis.ifas.ufl.edu.

2. Michael T. Olexa, Professor, Food and Resource Economics Department, Florida Cooperative Extension Service, Institute of Food and Agricultural Sciences, University of Florida, Gainesville, FL; Director, Agricultural Law Center, University of Florida, Gainesville, FL; and Chair, Agricultural Law Committee of The Florida Bar. Luke D'Isernia, former student (graduated cum laude in 2005), Levin College of Law, University of Florida, Gainesville, FL. Laura Minton, Attorney, Dean, Mead, Egerton, Bloodworth, Capouano, and Bozarth, Orlando, FL. Dulcy Miller, attorney, Foley and Lardner, LLP, Orlando, FL. Sarah Corbett, Attorney, Florida Second District Court of Appeal, Lakeland, FL.

The Institute of Food and Agricultural Sciences (IFAS) is an Equal Opportunity Institution authorized to provide research, educational information and other services only to individuals and institutions that function with non-discrimination with respect to race, creed, color, religion, age, disability, sex, sexual orientation, marital status, national origin, political opinions or affiliations. U.S. Department of Agriculture, Cooperative Extension Service, University of Florida, IFAS, Florida A. \& M. University Cooperative Extension Program, and Boards of County Commissioners Cooperating. Larry Arrington, Dean 
- The permitting of dredging and filling in waters of the state.

- Administering the Water Resources Act of 1972, Chapter 373, Florida Statutes.

- Review of water control districts.

- Regulation of air, water, and noise pollution.

- Solid and hazardous waste management.

- Public drinking water supplies.

- Controlling noxious aquatic weeds.

- Regulation of injection wells and wells related to oil exploration.

- The prevention or clean up of pollutant spills or discharges into inland waters or lands of the state.

- Administration of such federal acts as the Clean Water Act and the Safe Drinking Water Act in Florida.

\section{With Whom Does DEP Share Powers?}

The DEP has specifically delegated to the water management districts (WMD) power to administer and enforce the provisions of Chapter 373, Florida Statutes, also known as the Florida Water Resources Act of 1972. DEP has also given authority to the Department of Agriculture and Consumer Services (DACS), which regulates certain open-burning activities through the Division of Forestry.

\section{How Is the DEP Structured?}

The DEP is divided into seventeen divisions and the Office of the Secretary. Of these, the five most important are as follows:

\section{Administrative Services provides support} services for DEP, which includes personnel, accounting, and purchasing. Administrative Services contains four bureaus: Personnel Services, Finance and Accounting, Budget and Planning, and General Services.
2. Air Resource Management implements the federal Clean Air Act and appropriate Florida Statutes; monitors the state's air quality; administers the state's air pollution control programs; issues permits for sources of air pollution; and coordinates with other local, state, and federal air quality program efforts.

\section{Water Resource Management oversees programs} that help to provide safe drinking water; reclaim lands after they have been mined for phosphate and other materials; and implements ground water protection programs through permitting, compliance, and enforcement.

4. Waste Management is responsible for solid and hazardous waste management, including the cleanup of hazardous waste and pollutant spill sites. Waste Management contains three bureaus: the Bureau of Petroleum Storage Systems which administers the states above ground and underground pollutant storage tank regulation program and the petroleum cleanup program; the Bureau of Solid and Hazardous Waste which is responsible for the planning, management, permitting, and regulation of solid and hazardous waste; and the Bureau of Waste Cleanup which is responsible for all activities relating to the cleanup of sites, and for conducting investigations of ground water contamination. It also provides scientific and engineering technical assistance and reviews for the Division's non-petroleum cleanup programs, manages a Contaminated Soils Forum, issues the Voluntary Cleanup Tax Credits (http://www.dep.state.fl.us/waste/categories/vctc/ default.htm), and maintains the Institutional Controls Registry (http://gisweb.dep.state.fl.us/dwm/icr/) for contaminated sites.

\section{Division of Environmental Resource Permitting} is in charge of resource and wetland protection programs, including the Bureau of Aquatic Plant Management which regulates the control of noxious aquatic plants.

District offices of the DEP contain their own structure, which is usually similar to the one at Tallahassee headquarters. Collectively, the districts 
are responsible for policy, planning, and rulemaking activities. Each district is headed by a Director of District Management. Responsibilities for permitting, compliance monitoring, and enforcement activities are split between headquarters and district offices, although the districts do most of the work in these areas.

\section{Acknowledgments}

The authors are indebted to the personnel of both state and federal agencies who provided their time and advice in the preparation of this handbook. The authors are especially indebted to Richard Budell of the Office of Agricultural Water Policy of the Florida Department of Agriculture and Consumer Services for providing funds for the development of this publication. 